\title{
Some Procedural Aspects of the California Workmen's Compensation Law
}

\author{
Richard A. Bancroft*
}

$T^{-1}$ HE California workmen's compensation system has assumed a position 1 of major importance in the state's social and legal structure. It is a big business, deserving increased attention from lawyers. In 1951 nearly $\$ 117$,000,000 in direct premiums were collected by state and private compensation insurers. ${ }^{1}$ During the same year these insurers (exclusive of self insurers) made direct loss payments to injured workmen or their dependents in excess of $\$ 60,000,000 .^{2}$ These payments resulted either directly from Industrial Accident Commission decisions, or indirectly from voluntary settlement patterns established by Commission and court decisions. There were 32,641 decisions issued in $1951 ; 23,543$ originals and 9,098 supplementals. ${ }^{3}$ The upward trend has been steady. ${ }^{4}$

This volume of business was not contemplated by the original compensation act framers. ${ }^{5}$ The simplified procedures they intended have become very complex..$^{6}$ Unfortunately, however, both for lawyers and for students of public administration, there has been little analytical study and critical evaluation of these growing procedural complexities. ${ }^{\top}$

* LL.B., Howard University, LI.M., University of California, Berkeley.

1 The exact figure is $\$ 116,825,872.25$. See Montmur Report 5, Calm. Dept. of Irs. (March, 1952). This represented an increase of 20 per cent over 1950 direct premiums written. See letter of transmittal, $i d$.

2 The exact figure is $\$ 60,099,741.92$. 1951 state fund direct loss payments accounted for approximately one-quarter of this sum. (Personal interview, Statistics Section, Calif. Dept. of Ins., April 18, 1952.)

For comparable figures of 1950 see CaIIF. DEPt. OF INs., 83 ANN. ReP. Ivs. Comm'R 446450 , table 45 (1951). See also comparison between workmen's compensation and other forms of insurance as to premiums and losses, id. at 453 .

3 Carif. Dept. of IND. Red., 1951 Statistical Stmmary of Ind. Acc. Comor's Dec., pts. $I$ and II (1952).

4 See table of Commission filings and decisions from 1941 through 1950, Partial Report of Senate Interim Committee to the Senate on Workmen's Compensation Benefits, Calif. Legislature, 1951 Reg. Sess. 201 (filed April 13, 1951).

5 Prior to 1923 there were 13 referees who yearly handled about 275 claims each. Today each referee handles about 650 claims each year. Id. at 196-19' (letter of Supervising Referee Purvis).

6Id. at 209; Proceedings of the 36th Anmual Convention, 142 DEpt. OF LAB., Buneat or LAB. StAND. BuLc. 123, 132 (1950) (where Referee Douglas A. Campbell called for legislative action to remove procedural complications and technicalities); and 1945 Partial Report of Subcommittee of Assembly Interim Committee on Governmental Efficiency and Economy, Calif. Legislature, 1945 Reg. Sess. 121.

7 In a recent address, Referee Douglas A. Campbell termed the rules of procedure ... "[T]he traffic laws and highways for the flow of rights and benefits." Proceedings, supra note 6 at 133.

It may well be asked whether the liberal trends in workmen's compensation substantive law are not effectively hampered by the absence of a significant corresponding trend in procedural law.

The liberal substantive law trend is noted in Rresenferd, Forty Years of American Workmen's Compensation, 35 MnN. L. REv. 525 (1951), 7 NACCA L.J. 15 (1951); and Horovitz, Current Trendos in Workaten's Compensation (1947). But see RIesenfend, Basic Problems in the Administration of Workmen's Compensation, 36 Mrsw. L. REv. 119 (1952). Also see, 
This article is designed to provide only a brief survey of some of the more important procedural aspects of the compensation system, with special attention being paid to the place of the referee in that system.

\section{ORGANIZATIONAI STRUCTURE}

The workmen's compensation system is administered directly by the Division of Industrial Accidents, one of eight divisions within the Department of Industrial Relations. Until 1945 three of these divisions, the Industrial Safety Division, the Labor Research and Statistics Division and the State Compensation Insurance Fund were bureaus within the Commission. ${ }^{8}$

The policy making organ of the Division is the Industrial Accident Commission, which consists of seven Governor appointed members who serve four-year terms. ${ }^{9}$ It meets quarterly, adopts and amends procedural rules, decides policy and concerns itself with admimistrative matters. ${ }^{10}$ Some ambiguity exists concerning its administrative powers, for although one section of the Labor Code provides that the Division is under the control of the Commission, ${ }^{11}$ a later amended and more specific section vests the Commission only with judicial powers. ${ }^{12}$ Since 1945 these judicial powers have

for emphasis upon ađministrative aspects, RIESENFEID AND MAXwEIr, Modern SocIAL LEGISIATION 127-440 (1950) ; HOROVITZ, INJURY AND DEATH UNDER WORRMEN's COATPENSATION LAWS 382-399 (1944); Dawson, Problems of Workmen's Compensation Administration, U.S. DEPr.

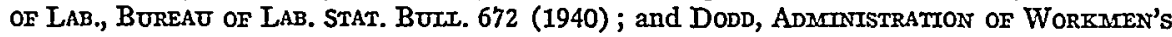
Compensation (1936).

8 Until 1945 the Director of the Department of Industrial Relations was also Chairman of the Industrial Accident Commission. See California State Governarent: A Guide to Its ORGANIZATION AND Functions 82-84 and 94 (1951). The 1945 legislation which altered commission structure is found at Cal. Stats, c. 1431 (1945). For a good description of the Commission and its bureaus before 1945 see HANNA, IndUStrial Accident Comonssion Practice AND Procedore, c. 3 (1943). For a discussion of the organizational changes the 1945 legislature proposed see Partial and Final Reports of Subcomnittee of Assembly Interim Committee on Governmental Efficiency and Economy, Calif. Legislature, 1945 Reg. Sess. The Partial Report also appears in CAL. Asstarbey J. 620-9 (1945 Reg. Sess.).

9 CAL. LAB. CODE $\$ \S 111-112$. The commissioners are not required to be lawyers. Two members of the San Francisco panel and one of the Los Angeles panel are lawyers. Although the Commission is not a tripartite body, apparently the governor is guided, in making appointments, by a desire to keep the Commission as representative as possible.

${ }_{10} I d$. $\$ 114$. The commissioners' only express powers are judicial, $i d$. $\S 111$, and those enumerated powers which may be considered as ancillary to the performance of its judicial duties. See $i d$. $\$ \S 115-134$. It may " . . do all things necessary or convenient in the exercise of any power or jurisdiction conferred upon it ...." Id. \$ 133. Presumably "any power" refers only to judicial or "ancillary" powers. Actually the commissioners advise the Commission chairman on administrative and policy matters. This is probably desirable.

11 Id. $\S 60$ (as amended in 1945): "The provisions of Division 4 of this code shall be administered and enforced by the department through the Division of Industrial Accidents which is under the control of the Industrial Accident Commission."

12 Id. §111 ("The Industrial Accident Commission . . . shall exercise all judicial powers .... In all other respects the Division of Industrial Accidents is under the control of the chairman of the commission ...."

Certain powers ancillary to the judicial power are specifically vested in the Commission. See $e . g ., i d$. $\$ \S 114$ (transfer matters from one panel to another); 117 (rent quarters, provide furniture and supplies); 126 (keep minutes, books and records); 127 (collect fees for documents and transcripts); 130 (administer oaths, certify to official acts and issue subpoenas); 132 (punish for contempt); 134 (issue writs or summons, warrants of attachment and commitment and all necessary process), and 5307 (adopt rules of procedure and regulate appearances, notices and proof). 
been exercised primarily by two panels of three commissioners each, with jurisdiction over two separate geographical areas in the state. ${ }^{13}$ Their main function is to decide appeals from referee decisions, but certain decisions must be issued over the panel members' signatures. ${ }^{14}$

\section{TEE REFEREE}

The key figure in the compensation system is the referee. He conducts all hearings required for both original and supplemental decisions. About 98 per cent of the 23,543 decisions the Commission issued in 1951 were actually made by Commission referees, and merely adopted by the Commission. ${ }^{15}$

One commissioner is designated to serve at the Governor's pleasure as Commission Chairman. ${ }^{16}$ It is the Chairman who bears the main compensation administration and enforcement burden and exercises department head powers over the Division. ${ }^{17} \mathrm{He}$ supervises the activities of the division's legal, medical and permanent disability rating bureaus and exercises ad-

But certain other powers specifically vested in the Commission seem to be administrative. See e.g., id. $\$ \S 114$ (provide, by rule, for geographical division of state and thus establish panel jurisdictions) ; 118 (appoint legal staff meunbers) ; 120 (appoint a secretary and assistant secretaries) ; 121 (authorize seeretaries to act as deputy commissioners and delegate authority to them as such) ; 123 (employ necessary assistants, officers, experts, statisticians, actuaries, accountants, inspectors, referees and other employees); 124 (fix compensation of all officers and employees of the commission); 127 (publish reports and pamphlets covering its operations).

Most of these administrative duties are performed by the chairman with soine advice froun the commissioners. And some of the ministerial functions ancillary to the Commission's judicial powers are performed by the chairman, e.g. rent quarters and provide furniture and supplies.

Apparently the 1947 amendment was intended to accomplish two things: (1) Suppleunent the 1945 legislature's external separation of judicial from administrative functions with soune internal separation. (2) Accomplish the division's virtual independence from the departinent. The extent to which the first has been achieved is a matter of some douht. As to the latter sce 13 Ops. Atr'y Gen. Car. 241 (1949).

Seemingly the 1951 amendment sought to remove any powers the Commission or the panels may have assumed they could properly exercise over personnel and coordination of panel and commission work. If so, other sections of the statute ought to be amended for the sake of consistency. See e.g., CAL. LAB. CoDE Sec. 114.

$13 \mathrm{Ibid}$. One panel is located in Los Angeles and the other in San Francisco.

14 Decisions granting or denying reconsideration; approving or disapproving counpromise and release; adjudgments for contempt and disciplinary and disbarment orders against attorneys or representatives. See Rules of Practice and Procedure of the IAC, 8 CAL. ADMIN. Code 10850. Effective August 1, 1952, thirteen of these Rules were amended. Hearings in these cases are held by referees and a recommended decision is made.

15 The text percentage represents an extension through 1951 of the identical result reported in a Department of Finance study of recent panel and referee decisions conducted at the Commission's request. The entire report is printed in the 1951 Partial Report, supra note 4 at 189.

Techmically, each referee decision is a Commission decision. CAI. LAB, Code $\$ 115$. Before certain 1951 amendments, referee decisions becaune final only after Commission approval. In most cases Commission approval was merely a pro forma issuance. Sce Report on Administrative Agencies and Tribunals, IAC, 25 CAIIF. STATE B.J. 315 (1950). Since the 1951 amendments, referee decisions are final when made, and may be announced at the hearing's close. Such decisions bind the Commission and the parties unless appealed. However, since all referce decisions are techmically Commission decisions, the Commission still performs the clerical function of issuance.

16 CAL. LAB. CODE $\$ 113$.

1r $I d$. $\$ 111$. Thus he is responsible for all except judicial activities, and as to these he is responsible for personnel and coordination of panel and Commission functions. 
ministrative controls over the referees. ${ }^{18}$ With the aid of an administrative assistant he hires, disciplines and prepares efficiency ratings for referees. A supervising referee in each of the two main offices is responsible for calendars and referee and reporter assignments and performs important liaison functions between the Chairman, the panels and the referees. ${ }^{19}$

\section{Who Are the Referees?}

California compensation referees are experienced civil service lawyers appointed by the Commission whose tenure and salaries are secured by the Civil Service Act and Personnel Board Rules. ${ }^{20}$ They are the most highly paid hearmg officers in the state. ${ }^{21}$ Although referees are Commission employees they are hired and disciplined by the Chairman.22 They exercise a Commission delegated adjudicative function. ${ }^{23}$ Although initially most referees came from private practice, virtually all new appointees have come from the Commission's legal staff. ${ }^{24}$ Turnover has been negligible with retirement and death the major factors. Many referees have served fifteen years or more. They acquire a sound understanding of industrial medicine, and generally become compensation law and procedure experts. ${ }^{25}$ Their competence universally commands practitioner respect.

Referees have been compared favorably with California's municipal court judges as to responsibilities and duties, difficulty of problems, extent

18 Hanna's description of these bureaus is accurate in every major respect. See HaNNA, op. cit. supra note 8, at 82-86.

19 Formerly each supervising referee was called Chief of the Compensation Bureau. Id. at $79-80$.

20 See descriptions of referee qualifications and inethod of appointment in 1951 Partial Report, supra note 4, at 184; HaNNA, op. cit. supra note 8, at 80 (1943); Trowbridge, The Functions and Status of Judicial Officers of the Industrial Accident Commission, 11 CALIF. StATE B. J. 205 (1936).

21 Under a 1951 amendment referee salaries are to be fixed "for a class of positions which perform judicial functions." CAI. LAB. CODE $\$ 123$.

Effective October 1, 1951, the range of Commission referee salaries was increased from $\$ 613-745$ to $\$ 710-862$. More than three-quarters of the Commission's referee receive the maxiInum. The most nearly comparable state officials receive monthly salaries within the following ranges: Referees, Unemployment Insurance Appeals Board, $\$ 530-644$; Class I Hearing Officers, Division of Administrative Procedure, \$530-644; Class II Ilearing Officers, Division of Administrative Procedure, \$613-745. See State Personnel Board, Pay Scates In the CatTr. State Civir Service 26, 39 (15th ed. Aug. 1, 1951).

22 Compare CAT. LAB. CODE $\$ 111$ with $\$ 123$.

23 Id. \$115. "Any investigation ... the commission has power to undertake ... and which has been assigned ... to a panel may be ... held ... by any referee attached to the headquarters of the panel to whom the matter is assigned." Compare Gallagher, Power of the Industrial Accident Commission to Settle Disputes, 27 CAIIF. L. REv. 241 (1939) with McGovney, The Industrial Accident Commission's Dilemma, 27 CALIF. L. REv. 266 (1939) as to the constitutionality of this delegation.

24 There are 46 referees. Six new ones were added in July, 1952. For a listing of referees see Personnel of Compensation Staff During 1951, 16 CAL. CoMrp. CASES (1951). Referee positions have become very desirable. Hearing officers from other state agencies seek transfers to the Commission's legal staff in order to have the opportunity to become referees. Several of the newer referees followed this course. The number of referees has rapidly increased simce 1941 when there were only 25. During the five year period which preceded 1942 the increase was about one a year.

25 See Trowbridge, supra note 20 , at 210 . 
of jurisdiction, value of judgments and qualifications. ${ }^{23}$ Although the importance of referee adjudicative functions has been recognized in past years, it deserves increased emphasis.

\section{What Functions Do Referees Perform?}

Referees are authorized to conduct hearings and make findings, orders, decisions and awards. ${ }^{27}$ They may hear testimony and argument, and decide fact and law questions and exercise other powers granted by statute, their orders of appointment and the rules of the Commission..$^{23}$ They are empowered to administer oaths, ${ }^{29}$ issue witness-attendance and document-production subpoenas, ${ }^{30}$ appoint trustees or guardians ad litem, ${ }^{31}$ provide for joinder of interested persons, ${ }^{32}$ grant continuances and adjournments, ${ }^{33}$ cause the taking of depositions and interrogatories ${ }^{84}$ and initiate contempt proceedings. ${ }^{.5}$

Within thirty days after the close of testimony they file fact findings and an award, order or decision to be served on the parties. ${ }^{20} \mathrm{~A}$ written report also must be filed as part of the record, separately stating fact findings and conclusions of law. ${ }^{3 T}$

\section{How Independent Are the Referees?}

Referee independence is not the burning issue in the workmen's compensation system that it is in some administrative agencies where hearing officer decisions may be influenced by an agency's investigative or prosecutive functions. ${ }^{38}$ Nevertheless the 1951 legislature accorded finality to referee original decisions in an atmosphere critical of a lack of referee independence.

${ }^{26}$ See Trowbridge, note 20 supra. And see Supreme Court Justice Shenk's testimony to that effect before the State Personnel Board in 1944, reprinted in the 1945 Partial Report, note 8 supta, CaL. Assembir J. at 625.

27 CAL. LAB. CODE $\$ 5309 ;$ Rules, supra note 14, \$9745. See HanNa, op. cit. supra note 8, at $80-81,207$. Also see Art. 61, $\$ 9$ of the unpublished Manual of Procedure of the Indzistrial Accident Commission which provides, "The Referee's primary function is to conduct hearings. . . U Upon him, basically, rests its judicial responsibilities. . . . [H] is the responsible representative of the Commission with whom the parties in that particular case come in contact."

28 CaL. LaB. Code $\$ \$ 5309-5310$. See Liberty Mut. Ins. Co. v. IAC, 73 Cal. App. 2d 555, 563,166 P.2d 908,913 (1946).

29 CAL. LAB. Code $\$ 130$.

30 Ibid. As to witness fees see CAL. LAB. Code $\$ 131$. Also see Rules, supra note 14, $\$ \$ 9736-7$; Manual, supra note 27 , Art. 33.

31 CAL. LAB. Code $\$ 5307.5$ (a). See Manual, supra note 27, Art. 36.

32 Car. LAB. Code $\$ 5307.5$ (b). See Rules, supra note 14. $\$ 9764 ;$ Manual, supra note 27 , Art. 45. See special party joinder provision for occupational diseases added in 1951. CAL. LAB. CODE $\$ 5500.5$.

33 Id. \$5700. See Rules, supra note 14, §§ 10770, 10774.

34 CaI. LaB. Code \$5710. See Manual, supra note 27, Art. 44.

35 CAL. LAB. CODE $\$ 132$.

36 Id. $\$ 5313$. See Rules, supra note 14, $\$ 9746$. Art. 64 .

37 CAL. LAB. CODE $\$ 5313$. See Rules, supra note 14, \$\$ 9747-50; Manual, sispra note 27,

38 See Davis, Administrative LAw c. 10 for excellent detailed analysis of separation of functions in federal administrative agencies under the federal A.P.A. Professor Davis states, at page 402, "The real problem about complete separation concerns agencies whose work is largely prosecuting." 
In the past the relationship between the referees and the panel members has been characterized by bitterness. Referee resentment was expressed against reversal of their decisions and findings, especially credibility findings, by panel members who often were not lawyers and who, assertedly, did not understand due process requirements. Commissioners complained of the civil service tenure of the referees as compared with their four year terms and of a resultant practical inability to correct or discipline them..$^{30}$

Since 1945 the bitterness has decreased but it has not altogether disappeared. Some referees still resent the fact that all panel members are not lawyers. However, since 1945 most panel members have been reappointed and several of them have served as Commission Chairman. Most of them have had other experience in the Commission as members of the legal staff, referees or both. The continuity among the present panel members, their selection from within the agency, together with a sharper delineation between panel and referee functions, should tend to eliminate rancor.

Much of the federal and state experience involving hearing officer independence is inapplicable to the compensation referee system. The compensation system is not self-executing. Its hearing machinery may be invoked only through a filed application..$^{40}$ No compensation official ever appears in a referee hearing as an advocate or prosecutor armed with the results of an investigation. Although the Commission's medical or permanent disability rating experts testify in compensation hearings, they are not advocates of Commission policy. They are privileged to express and defend their own opinions as are other experts. A referee is never asked to uphold a Commission or Division act or conclusion.

Referees, in seeking assistance on difficult cases, may consult with legal, medical and permanent disability rating experts on the Division's staff. ${ }^{41}$ They also consult other referees. This not only need not make the referee's decision less impartial, but probably improves its quality. Proper safeguards require the results of these consultations be entered in the record.9

The Division Chairman's powers to hire, discipline, assign and transfer referees, along with the Commission's power to issue binding procedural rules, apparently represent legislative approval of some administrative

39 For a sampling of the bitter feelings which existed in 1945 see 1945 Final Report, supra note 8. See especially, testimony of the then Commission Chairman, Paul Scharrenberg, present Director of the Department of Industrial Relations. Id. at 11-12. See also id. at 130-132 as to referee credibility findings and due process.

10 CAI. LAB. CODE $\$ \$ 5500$ and 5501. See Rules, supra note 14, $\$ 9780-86$, and Manual, supra note 27, Art. 60.

41 Cat. Lab. Code $\$ 5703$ (b). See Hanna, op. cit. supra note 8, at 82-86.

42 See CAL. LAB. CODE $\S 5704$. "Transcripts of all testimony taken without notice and copies of all reports and other matters added to the record, otherwise than during the course of an open hearing shall be served ...., and an opportunity shall be given to produce evidence in explanation or rebuttal thereof before decision is rendered." (Emphasis added.) The italicized words should not be narrowly construed to permit withholding from the record of ex parte evidence. Compare Rules, supra note 14, § 10771 with Manual, supra note 27, Art. 38, § 5. And see id. Art. 38, § 11. "All evidence upon which the Coinmission rehes for action shall be contained in the record either directly or by appropriate reference." 
control. Even an abuse of these powers would suggest only that the abuses be corrected, not that complete separation be afforded.

\section{What Is the Effect of the 1951 Amendments?}

The 1951 legislature adopted certain amendments designed to increase referee stature. One amendment authorized referees to make original, not merely recommended, decisions by eliminating the bracketed words and inserting those italicized in the following excerpt: ${ }^{43}$

"Every finding, order, decision or award made and filed by any commissioner or referee pursuant to such investigation, mquiry or hearing [when approved and confirmed and ordered filed by a panel] is the finding, order, decision, or award of the commission unless reconsideration is had in accordance with the provisions of Article 1, Chapter 7, Part 4, Division 4 of this code."

Apparently this change merely approved a Commission practice authorizing referee issuance of original decisions without review in most classes of cases. ${ }^{44}$ But the amendment not only destroyed a statutory fiction that all decisions were Commission decisions, it also demonstrated the legislative intent to make compensation decisions more personal and to enhance referee status. ${ }^{45}$

43 CAC. LAB. CODE \$ 115. This reform was first called for in McGovney, supra note 23, at 273, based upon information provided in Gallagher, supra note 23, and Trowbridge, stipra note 20. In 1941 a State Bar Committee supported it. Proceedings of the Fourteenth Annual Meeting of the State Bar, 327 (1941). A legislative committee recommended it in 1945. See 1945 Final Report, supra note 8 at 91. In 1950 a State Bar Committee in a Report on Administrative Agencies and Tribunals strongly opposed the "outmoded procedure." Supra note 15 at 317-18. It was finally adopted after twelve years of criticism and after another legislative committee proposed it. See 1951 Partial Report, supra note 4 at 185-187, and later Partial Report of Senate Interim Committee to the Senate on Workmen's Compensation Benefits, Calif. Legislature, 1951 Reg. Sess. 6-8. (Filed May 11, 1951.)

44 Before the 1951 amendments, Commission review of referee decisions was pro forma in all but a few cases. See note 15 supra. See Rules, supra note $14, \S \S 10850$ (12 classes of decisions could be issued only over the signature of a majority of a panel's members); 1085 I (two classes could be issued over the signature of individual panel member subject to panel approval); 10852 (referee signature was authorized in all cases except those specifically reserved by $\$ \S 10851-2$ above, but "subject to approval ... by the panel ...") and 10853 which provided that the Commission will prepare and serve all decisions.

The decisions for which referee signature was authorized were not reviewed, but were merely listed in groups for panel member signatures. These were called "minute orders." The decisions, which were required to be issued over signature of a panel member or majority, were approved through a "monitor system" in which a reviewing referee's recommendations were considered by the panels. For an early description of these "referee" and "Commission" decisions see Gallagher, supra note 23 at 243-245.

After the 1951 amendments were adopted the Commission amended its rules effective September 22, 1951. Under these amendments only four types of decisions are reserved for Commission or panel issuance. (Two from the former group of twelve and two new ones.) $\$ 10850$ as amended. In place of the two types of decisions, formerly permissively issuable by a single panel member, there are substituted eight types of decisions a commissioner, "or, in case of an emergency, ... the Supervising Referee, Secretary, or Assistant Secretary" may issue. \$10851. The new $\S 10852$ authorizes referee issuance of any decision in any "claim assigned for hearing or other disposition, except those expressly reserved for issuance by the Commission, a panel, or a commissioner, by law or rules of the Commission." Section 10853 which required Commission preparation and service of all decisions has been eliminated.

45 See 1951 Partial Report (filed May 11, 1951), supra note 43 at 6-8. "Referees should decide the cases which they hear." Id. at 7. For a good comparison of the advantages and disadvantages of institutional decisions see DAvIs, op. cit. supra note 38 at 353-359. 
Another amendment repealed a provision which authorized the Commission, at its option, to require its referees merely to hold hearings and return the testimony to the Commission. ${ }^{46}$ But the effect of this provision seems to have been retained through a 1951 amendment to another section which permits the Commission to "remove to itself ... the proceedings on any claim" formerly assigned to a referee. ${ }^{4 \mathrm{~T}}$

Another amendment which may be viewed as part of the statutory scheme to enhance referee status requires that courts reviewing Commission decisions examine the entire record in applying the substantial evidence test. ${ }^{48}$ In view of the Supreme Court opimon in Universal Camera Corporation $v . N L R B$, which interpreted a similar provision to require that a hearing officer's recommendations reversed by an administrative board be considered as detracting from the substantiality of the evidence in support of the board's conclusions, it is likely that this amendment will lead the Commission and the courts to attach more weight to referee hearing room observations. ${ }^{49}$

The present referee decision seems to be the product of a happy blend of personal and institutional methods. If changes inust be made they should reflect close study of compensation procedure peculiarities rather than indiscriminate borrowing from incomparable experiences undergone by other state and federal agencies. And if borrowing is to be done, the compensation statutes of other states, the federal government and other countries are the proper sources. ${ }^{50}$

\section{Are Referees Judges?}

The Commission has been dubbed a court ${ }^{51}$ and the referees have been termed "judicial officers." "52 While referees do perform functions.formerly carried out by judges, only a narrow separation of powers conceptualism requires that they be called judges. ${ }^{53}$ The use of such terms creates a risk

46 Car. Lab. Code $\$ 5314$.

47 Id. $\$ 5310$. But it may be argued that the power to "remove to itself" is narrower than the power to "require its referees merely to hold hearings and to make return of the testimony to the Commission."

$48 I d . \$ 5952$.

40 Universal Camera Corp. v. NLRB, 340 U.S. 474 (1951). See 40 CaIIF. L. Rev. 119 (1952) for a discussion of the likely effect of this amendment upon court review of Commission decisions.

50 The reports of the 1949 and 1951 Senate Interim Committees disclose careful study of state, territorial and federal but, with one exception, not foreign compensation laws. See the 1947 and the 1949 Report of Senate Interim Committee on Workmen's Compensation Benefits, Calif. Legislature, 1947 and 1949 Reg. Sess. The exception appears in the study of a permanent disability rating plan. 1949 Report at 15 .

$51 \mathrm{By}$ the courts. See e.g. Bankers Indemnity Ins. Co. v. IAC, 4 Cal. 2d 89, 47 P.2d 719 (1935); Carstens v. Pillsbury, 172 Cal. 572, 158 Pac. 218 (1916) ; West v. IAC, 79 Cal. App. 2d 711, 180 P.2d 972 (1947); Mass. Bond. \& Ins. Co. v. IAC, 74 Cal. App. 2d 911, 170 P.2d 36 (1946). By witnesses before legislative committees. See 1951 Partial Report, supra note 4, at 209-17. By commentators. See e.g. Trowbridge, supra note 20 at 207; Gallagher, supra note 23 at 242; McGovney, supra note 23 at 276; Comment, 24 CAIIF. L. Rev. 328 (1936). But see Kleps, Certiorarified Mandamus, 2 StAN. L. Rev. 285, 292 n. 27 (1950) and Radin, The Courts and Administrative Agencies, 23 CAITF. L. Rev. 469, 473 (1935).

62 See $e . g$. Trowbridge, supra note 20 at 210.

53 See Kleps, note 51 supra. See generally McGovney, Administrative Decisions and Court Reviev, 29 CaLIF. L. Rev. 110 (1941). 
that technical courtroom standards may increasingly be applied to Commission procedures in direct opposition to constitutional and statutory provisions. $^{54}$ The language in court opinions terming the Commission a court was in each case mere dicta which should not be extended so as to convert the referee into a judge. ${ }^{55}$

\section{CHARACTERISTICS OF REFEREE HEARINGS}

The State Constitution commands that compensation act administration "accomplish ... justice . . expeditiously, inexpensively and without incumbrance of any character." 56 The statute requires informal proceedings and a manner of inquiry "best calculated to ascertain the substantial rights of the parties."

\section{Expense}

The state policy is to maintain costs at a minimun in order to keep awards intact. Except for transcripts of testimony and copies of papers, the Commission charges no fees for its acts, the filing of any paper or the issuance of any process. ${ }^{58}$ Parties pay inoderate witness fees. ${ }^{50}$ The employer must reimburse an employee or his dependents for expenses incurred for $\mathrm{x}$-rays, laboratory fees and medical reports required to successfully prove a contested claim. ${ }^{60}$ These charges seem not to have invoked criticism.

There is room for argument, however, that the present system's authorization of deductions from employee's compensation awards for representative's fees is inconsistent with the concepts that the compensation award should be left as near whole as possible, and that these proceedings should be inexpensive. Despite the framers' original intent, injured employees increasingly need expert representation. Accordingly, the legislature should devote some attention to the question whether reasonable legal fees required

54 Note emphasis upon judicial due process in testimony of witnesses before legislative committee investigating a "Legalistic Approach." 1951 Partial Report, supra note 4, at 209-217.

Despite the separation of powers provision of CAI. Consr., Art. XXX, § 1, the workmen's compensation system was authorized to exercise judicial power whether the legislature saw fit to create an administrative agency or a court. Id. Art. XX, § 21. The legislature established an administrative agency which combined administrative and judicial functions. Cal. Stats., c. 586 (1917), replacing the Boynton Act, Cal. Stats. c. 176 (1913), and the Roseberry Act, Cal. Stats. c. 399 (1911). A form of judicial review typical of administrative agencies is provided. CAI. LAB. CODE \& 5952. Although this is not definitive, it is indicative of legislative intent.

55 In each of the cases cited supra at note 51 the courts had only to decide whether the Commission could validly exercise the challenged power.

86 Cat. Const. Art. XX, \& 21.

$5 T$ CAL. LAB. CODE $\$ \S 5708-5709$.

ss Compare id. $\$ 127$ (a) with Rules, supra note $14, \S 9735$. The statute allows charges for process service. CAT. LAB. CODE $\$ 134$. But the Coinmission, by rule, waives them. Rules, supra $\$ 9735$.

59 CaL. LaB. Code $\S 131 ;$ Rules, supra note 14, $\S 9736-9737$. The calling party pays the same fees as are paid in the superior court. Independent medical examiners receive $\$ 25.00$ for the first two hours or less, and $\$ 10.00$ additional for each hour or fraction thereof beyond the first two hours.

60 CAL. LAB. CODE $\$ 4600$ : "In accordance with the rules of practice and procedure of the commission, the employee, or the dependents of a deceased employee, shall be reimbursed for expenses reasonably, actually, and necessarily incurred for x-rays, laboratory fees, and medical reports required to successfully prove a contested claim." The Commission's rules unaccountably omit laboratory fees. Rules, supra note 14, \& 10804. 
to successfully prove a contested claim should not be borne by the employers who ultimately can shift the loss, through insurance, to the public. ${ }^{61}$

\section{Speed}

The compensation system is remarkable for its efficiency and speed. Approximately 80 per cent of all cases heard in 1951 required only one hearing. ${ }^{62}$ The average hearing consumed about an hour. ${ }^{63}$ More than half the claims were decided within three months after being filed. ${ }^{\text {.t }}$

Hearing room time is conserved through pre-hearing filing of medical reports and other evidence. ${ }^{65}$ The simplified fact pleading, by application and optional answer, does not often serve to eliminate issues, ${ }^{66}$ but referee techniques in securing stipulations near the beginming and during the course of the hearings usually reduce the contested issues to two or three. ${ }^{67}$

Speed is achieved through referee interrogation of witness for both sides, and especially by questions addressed to the claimant designed to determine whether a prima facie case exists. Referee skill, prestige, and opportumity to lead witnesses can quickly elicit all relevant testimony, particularly where witnesses are of low mentality or are unwilling to answer questions posed by counsel. ${ }^{6 s}$ Referees feel that this does not compromise their position as unbiased adjudicators.

61 This proposal was advanced in 1934 by Warren H. Pillsbury in a letter to the State Bar Committee on Practice and Procedure Before the Industrial Accident Commission. Pillsbury argued that the increase in insurance premiums would be negligible and that the Commission could prevent abuse by failing to award an attorney for extra steps unnecessarily performed. See Contmittee Reports Part II, 9 CaL. State B. J. 76, 80 (1934). See also testimony before 1951 Senate Interim Committee. 1951 Partial Report, supra note 4 at 285.

62 StatisticaI SUMATARY, supra note 3.

63 Ibid.

os Ibid.

6. Written stipulations may be filed before the hearing. CAL. LAB. CODE $\$ 5702$. See Rules, supra note 14, $\$ 10744$. See HANNA, op. cit. supra note 8 at 192.

Complete reports of all employee injuries arising out of or in the course of employment are to be reported by employers, insurers and attending physicians to the Division of Labor Statistics and Research. CAL. LAB. CODE $\$ 6407$. Failure to do so is a misdemeanor. $I d, \S 6410$.

Commission rules require original, signed reports of physicians be filed and served on the adverse party within five days of the filing of an application. In some instances copies are acceptable. Rules, stipra note $14, \$ 10794$. There is a continuing duty to file later physician's reports within five days of receipt. Id. $\$ 10795$. Parties in control of $x$-rays inust file them immediately. Id. $\$ 10796$.

Copies of non-medical reports and records must ordinarily be served upon the adverse parties five days before the hearing. Id. $\$ 10790$.

60 See note 164 infra. "Where the question is defined by the nature of the proceeding and does not depend upon the circumstances of the particular case, formal pleadings are not necessary." Clark, Code Pleading 69 (1947).

67 "The respective parties shall be required to state the issues with respect to which they desire to be heard. The Referee shall thereupon frame stipulations and outline the issues. The evidence to be received shall be material to such issues." Manual, supra note 27 Art. 38 \& While the Commission urges stipulations to avoid "unnecessarily prolonged hearings," the referee is instructed not to waste time in securing them, but rather to "cover the point by an issue and go ahead." Id. Art. 70 \$ 7.

68 The Commission cautions against leading questions by referees unless the "low mentality" of a witness requires them. Manual, supra note 27 Art. 38, $\$ 21$ (D) (c). Referees are urged to be "completely impartial." Ibid. Unnecessary interruptions of cross examining counsel are 
Opening and closing statements are rarely allowed. ${ }^{69}$ The filing of points and authorities is favored..$^{\text {T0 }}$ Use of documentary evidence is encouraged on most issues. ${ }^{71}$ But referees prefer to observe witness response and demeanor on issues which involve witness reliability or credibility. Thus, when the proof hes within the competence of available lay witnesses, the issue turns on complicated questions of medical or scientific opinion, or when lay testimony may raise a conflict with competent medical testimony, oral presentations are desirable.

The Commission is constantly seeking new means to speed its procedures and it is anticipated that referee original decisions will aid these efforts. ${ }^{72}$

\section{Lack of Procedural Encumbrances}

Ordinarily, hearings are subject to a minimum of procedural requirements. Referees are not bound by the exclusionary rules of evidence. ${ }^{73}$ Rather, Commission rules urge they seek "the best evidence under the circumstances." The proceedings are informal. ${ }^{75}$

Referee discretion in admitting evidence is virtually unlimited. ${ }^{70}$ Facts may be proved through reports of physicians, special scientific investigators and employers; hospital records; Commission, state and federal publications; expert testimony and prior Commission decisions involving similar

counselled against, id. $\$ 14$, especially where they might save a witness who is weakening. $I d$. $\S 14(A)$. Leading questions in hernia cases are especially warned against. Id. Art. $39, \S 8$.

But the referee is to control the record and see that it is not burdened "with extraneous evidence or discussions." Id. Art. $38, \S 13$. He is advised to conduct his examination rapidly in order to discourage interruptions. Id. Art. $38 \$ 21(\mathrm{D})(\mathrm{g})$.

69 They may be allowed in complicated cases if the referee is confident they will be concise and helpful.

70 See HANNA, op. cit. supra note 8 at 211. "The parties in interest, however, may state for the record in a succinct manner their position as to any question of law or fact involved in the case." Manual, supra note 27 Art. $38, \S 13$ (A).

71 For expressions of Commission's preference see Manual, supra note 27 Art. 27, $\$ 2$ and 6(C) and (I).

Payroll records on the issue of earnings and employnnent, birth and marriage certificates on the issue of dependency and medical reports on the issues of imjury and disability are samples of preferred evidence. See HANNA, op. cit. supra note 8 at 212 .

i2 See Statement of Commission's Chief Counsel that the 1951 legislation may speed procedures. Thomas, Workmen's Compensation, 3 ANNuAL SuRvey Carif. Law 113, 119 (1951). From the point of view of the injured workman, the speed of these proceedings is probably open to doubt. Since his wages frequently meet only current expenses, the complete loss of income, where liability is contested through the Commission and the courts, requires resort to borrowing from friends and securing state welfare aid. Can practical provisional remedies be devised?

73 CAI. LAB. CODE $\$ 5708$.

$74 \mathrm{Manual}$, supra note 27, Art. 61, §6. The manual contains a thorough exposition of Commission policy affecting the admissibility of evidence. For example, "Immaterial, irrelevant, cumulative and unduly repetitious evidence may be excluded .... However, care should be exercised that testimony of reasonably probative value to establish any pertinent fact be not excluded." Id. Art. $27, \S 6$. See also $\S 6(\mathrm{~B}),(\mathrm{F})$ and $(\mathrm{H})$ for tests by which referees are to be guided.

75 CAL. LAB. CoDE $\$ 5709$. Informalities may not invalidate any decision.

i6 Ibid. "The sound discretion of the Referee is, of course, the final basis of all his rulings." [on objections to evidence]. Manual, supra note 27, Art. 38, \$21(D) (e). See HaNNA, op. cit. supra note 8 at 211 . But hearsay evidence is to be avoided when competent evidence is available. Manual, supra note 27, Art. 61, \$6(E). 
scientific fact issues in other cases, referee premise view conclusions and $\mathrm{x}$-rays, photographs and movies. ${ }^{77}$ Hearsay or lay opinions may be an award's sole support. ${ }^{\text {? }}$ The residuum rule requiring some competent evidence is not applied. ${ }^{79}$ Ex parte evidence may be added to the record, but only if rebuttal opportunity is afforded..$^{00}$ Party objections more often are asserted to alert the referee to the weak nature of the evidence, and to avoid waiver contentions on review, than to achieve its exclusion. ${ }^{81}$ Referees seldom exclude evidence a party insists upon presenting. ${ }^{82}$

In the usual compensation case the applicant is the sole witness. In the more complex cases there may be many additional witnesses including applicant and defendant lay and expert witnesses, Commission experts, and Commission appointed independent experts. The techniques useful in eliciting testimonial evidence in non-jury trials are generally applicable before referees, with whatever adjustments are required by time and expense considerations, the greater value of documentary evidence, referee discretion in controlling transcript volume, referee expertness on the specialized issues they decide daily, and referee participation in witness interrogation. These adjustments usually result in fewer witnesses, little repetition, and pointed, material testimony. Written questions are frequently used, especially for expert witnesses.

But some aspects of a stricter system still affect witness interrogation. For example, some referees will not allow leading questions on direct examination, except on preliminary or merely formal matters, even when harmless and there has been no objection. Since the referee and not a jury determines what weight is to be given to responses to leading questions it is difficult to justify this disallowance. ${ }^{83}$

A similar techmicality imposed by Commission rule restricts the cross examination of experts to the scope of the direct examination. ${ }^{84}$ This seems an anachronism in view of the modern trend of authority and the Commission's efforts to liberalize its rules. ${ }^{85}$ Cross examination of Commission and

77 CAL. LAB. CODE $§ 5703$.

78 Hearsay itself may be sufficient. Sada v. IAC, 11 Cal. 2d 263, 78 P.2d 1127 (1938). Applicant's testimony as to pain is sufficient. West v. IAC, sacpra note 51 .

79 CAL. LAB. Code $\$ 5709$ provides .... "No order ... shall be invalidated because of the admission into the record, and use as proof of any fact in dispute, of any evidence not admissible under the common law or statutory rules of evidence and procedure." Some state courts have interpreted similar language as requiring a residuum of legal evidence. See DAvIS, ADMINISTRATIVE LAw 458 et seq. This interpretation was rejected by the California Supreme Court in London Guarantee \& A. Co. v. IAC, 203 Cal. 12, 14-15, 263 Pac. 196 (1927). Cf. Pac. Emp. Ins. Co. v. IAC, 47 Cal. App. 2d 494, 499, 118 P.2d 334 (1941).

80 CAL. LAB. CODE $\$ 5704 ;$ Rules, supra note 14, § 10771. See note 42 supra.

81 See HaNNa, op. cit. supra note 8, at 351 .

82 See Manual, supra note 27 Art. 38, \$21(D) (e). "When the Referee is in doubt as to the admissibility of evidence, it is better to overrule the objection and possibly admit incompetent, irrelevant or immaterial matter rather than defeat the record by leaving out that which may subsequently prove to be material, relevant or competent."

83 Unless it may be argued that referees thus seek to teach counsel that answers to leading questions may count for hitle in the weighing process.

84 See Manual, supra note 27, Art. 38, \& 21(D)(i) (b).

85 See 6 WigMORE, EVIDENCE $\$ 1885$ et seq. (3rd ed. 1940) for a criticism of improper limits upon scope of cross examination. His criticisms are the more applicable in an informal, non-jury proceeding. 
other experts is virtually a fruitless endeavor unless it may be shown to the satisfaction of the referee that the expert was not reasonably qualified to give the opinion, based his conclusion on incomplete or incorrect facts, engaged in mere surmise or was biased. ${ }^{86}$ Restricting the cross examination to the scope of the direct would only make this already difficult task of impeachment more difficult. This limitation seems particularly unnecessary where a skilled referee and not a jury is to weigh all the evidence. Actually the rule is seldom, if ever, observed. Yet its continued existence unnecessarily affords a potential source of litigation.

In comparison with most courtroom standards compensation hearings are relatively unencumbered. Nevertheless, in some instances, particularly when the issues are complicated, referee rulings become technically strict and incomprehensible to laymen.

\section{Rapid Decision}

The referee system demands that practitioners simultaneously pursue dual objectives of assisting referees toward favorable findings adequately supported, and building a good record. The record's value is not limited to later Commission or court review. Its more immediate value is in convincing the referee who uses it to make his decision.

As near the hearing's close as possible, referees dictate to a hearing reporter a summary of the record and their impressions from the testimony to be transcribed and added to the record. As soon thereafter as their schedule allows they prepare and file a referee report and their findings and award, separately stating their conclusions of fact and of law. ${ }^{87}$ The report and the decision may now be mailed to the parties over the referee's signature. They are final subject to Commission reconsideration, ${ }^{88}$ court review, ${ }^{89}$ and the Commission's continuing jurisdiction. ${ }^{00}$

\section{FINALITY OF DECISIONS}

It is easy to overemphasize the finality of referee decisions in view of the fact that only one or two per cent of the cases are reversed by the Commission..$^{01}$ But referee decisions, formerly disguised, by adoption, as

86 See HaNNA, op. cit. supra note 8 , at 348-9.

87 The report and the findings and award are required by CAL. LAB. CODE \& 5313. Since the 1951 legislature authorized original referee decisions $\$ 9749$ of the Commission's Rules, supra note 14, has been amended and now specifies the content of this report. Paragraph (C) of this section requires that "The report . . . set forth . . . the reasons for the decision made, together with essential findings of fact and conclusions of law." The form of this report is described in Manual, supra note 27, Art. 64, $\$ 2$ and was applicable only to referees. Referees, in their discretion, may discuss the weiglt of the evidence and their reasons for particular conclusions. Id. \$2(N). However, paragraph (C) of the Rules, supra, applies to both commissioner and referee reports on decisions. Query: Does this mean the panels must issue reasoned decisions? Will they be published? In accordance with former panel practices as to record review, will the writing of reasoned decisions, if there are to be any, be delegated to a referce?

88 CAL. LAB. CODE $\$ \$ 5900-5911$. See text at notes 97-118 infra.

89 CaL. LaB. CoDE $\$ \$ 5950-5956$. See text at notes 119-123 infra.

90 See text at notes 93-96 infra.

911951 Partial Report, supra note 4 at 189. See note 15 supra. 
Commission decisions, were also reversed by the courts. ${ }^{92}$ It is to these Commission and court reversals that attention must be given in order to determine when referee findings may be upset.

\section{Commission Review}

The posture a claim assumes may change several times during the Commission's five-year continuing jurisdiction. ${ }^{93}$ Each year there are almost as many supplemental as original decisions. ${ }^{94}$ Supplemental decisions are issued in response to petitions which seek award modification or termination based on alleged mistakes of law or fact, changed physical condition or other conditions which make further Commission action equitable. ${ }^{95}$ However, since petitions to reopen more often involve post-hearing considerations, such as changed physical condition, then errors alleged to have occurred during the hearing, they will not be treated in this discussion. ${ }^{96}$

The extent to which the Commission's power to review will be exercised apparently depends on whether review is sought through reconsideration on motion of a party or on that of the Commission..$^{97}$

Reconsideration on its own motion. The Commission has ruled that reconsideration on its own motion "will be used to insure uniformity of decision, liberality of interpretation, compliance with interpretative regulations, and to permit consideration of matters of first impression and important questions of law." 98 This broad type review is seldom apt to result in reversals for other than technical reasons since it presents difficult administrative problems and party petitions probably will increasingly occupy

92 Dissatisfaction has been expressed with court denials of many petitions for writs of review without opinion, and with the small percentage of cases reviewed. See 1945 Final Report, supra note 8 at 89, 117. Also see Report on Administrative Agencies and Tribunals (1950), supra note 15 at 318 .

${ }^{93} \mathrm{~A}$ Commission decision may be rescinded, altered or amended for good cause at any time within five years from the date of the injury, upon notice and opportunity to be heard. Cac. LAB. CODE $\$ \$ 5803-5805$. But a finding of employment may not be altered if the statutory periods for reconsideration and review have expired. Id. \$ 5804. See HANNA, op. cit. suspra note 8 at $236-240$.

O4 There were 9,098 in 1951. Statistical Summary, supra note 3, pt. II. The number of supplemental decisions bas increased more sharply than original decisions since 1945. For a good discussion of supplemental proceedings see HANNA, op. cit. supra note 8 at 236-242. "Any pleadings which are filed subsequent to the issuance of a finding and award are supplemental." Id. at 240 .

${ }_{05}$ The most common of these supplemental petitions seek reconsideration, reopening, termination, past medical expense, further medical treatment, supplemental medical expense, further benefits for reeurring disability, permanent disability rating, liens, commutation and compromise and release. See generally HANNA, op. cit. supra note 8, cc. 10 and 11.

${ }^{96}$ See CAL. LAB. CoDE $\$ \$ 5803-5805$. Reopening is based on the Commission's continuing jurisdiction which exists to permit equitable adjustments for "good cause" because of changed physical condition, mistakes of fact, madvertence, material new evidence or fraud. It has occasionally been construed to permit correction of errors of law or of fact. See HANNA, op. cit. supra note 8 , at $236-240$.

o7 See note 110 infra. Reconsideration may be had with or without further proceedings. CAL. LAB. CODE $\$ 5906$. See Moore v. IAC, 13 CAL. CoMrp. CASEs 237 (1948) (writ denied without opinion). A decision on rehearing conforming to recommendation of trial referee but contrary to recommendation of rehearing referee does not violate due process. Schibsby v. IAC, 10 Car. Comp. Cases 229 (1945) (writ denied without opinion).

98 Rules, supra note $14, \S 10877$. 
panel time, but its desired effect largely may be achieved through its mere existence and occasional application.99

Reconsideration on party motion. When a party petitions for reconsideration, his petition is referred to the concluding trial referee who has the power to grant but not deny the petition, since only a panel can deny reconsideration..$^{100}$ If the referee recommends demal, his report is referred to the reviewing referee who makes a further recommendation for panel approval or disapproval. If he recommends the petition be granted, the case is referred to another referee for further proceedings or reconsideration. The reconsidering referee prepares a report containing proposed findings on each issue, reports of hearing if any have been held, and submits, for panel or Commission signature, appropriate findings and a decision. ${ }^{101}$ If the reviewing referee recommends against reconsideration, the petition is sent to a panel of the Commission. The panels never hear testimony. Until 1952 even arguments before panels were almost never allowed. ${ }^{102}$

A panel need read neither the record nor the transcript when it affirms the conclusion of the trial referee or even of a deciding referee who didn't hear all the evidence but who has read all the record and the transcript. ${ }^{103}$ However, when it reverses the deciding referee, it must read the record but not necessarily the transcript. ${ }^{104}$ Professor Davis in his recent volume on Administrative Law recommends that federal and state governments study this system. ${ }^{105}$ Two questions arise. Must panel members personally read the record or may they delegate this duty to a reviewing referee? If they must read the record, need it be in its entirety or only selectively?

The statute provides no clear answer to the first question. However, since the Commission may delegate its hearing and deciding functions, ${ }^{100}$ the only question seems to be whether record review is simply another delegable function. The panels seem to have resolved this problem, however, by yielding to court decisions which intimate panel review must be personal. ${ }^{10 \pi}$

${ }^{99}$ Currently every fifteenth case decided in the San Francisco office is submitted to review by an experienced referee who serves as a secretary to the Commission. His review consists mainly of looking for technical errors, obvious errors in deciding, violations of Commission procedural rules and gross errors of law. He emphasizes that he does not attempt to substitute judgment.

100 Id. $\$ 10850$.

101 Id. $\$ 10878$.

102 The San Francisco panel has heard arguments in five or six cases since the beginning of 1952 in what the panel terms "hardship" cases. infra.

103 Helmick v. IAC, 46 Cal. App. 2d 651, 116 P.2d 658 (1941) and cases cited at note 137

104 Nat. Auto \& Cas. Co. v. IAC, 34 Cal. 2d 20, 206 P.2d 841 (1949); Taylor v. IAC, 38 Cal. App. 2d 75, 82, 100 P.2d 511, 515 (1940) "It is at once apparent that the very object of the statute is to enable the Commission to use the report of the referee in its entirety or in part as the basis for a decision or award, or if dissatisfied with such referee's report, the Counmission is authorized to resort to the record in the case." In Calif. Shipbuilding Corp. v. IAC, $27 \mathrm{Cal} .2 \mathrm{~d}$ 536,165 P.2d 669 (1946) it was held that the Commission in affirming a rehearing (now reconsidering) referee's decision need not read the petition for rehearing or the transcript.

105 Davis, AdMmistrative Law 342, 364 (1951).

106 CAL. LAB. Code $\$ 115$.

${ }_{10 \pi}$ See e.g. Helmick v. IAC, supra note 103. When it reverses, "a review of the evidence by the Commission is required." Id. at 656 . 
Even if panel record review must be personal, reading the entire record is not essential. ${ }^{108}$ Consequently, San Francisco panel members skim and explore for errors against which petitioner's objections are assigned and ignore immaterial and cumulative portions. ${ }^{102}$ This practice seems sound since it properly burdens petitioners with specifically identifying the portions of the record where alleged error appears. Where the asserted error appears only in the transcript which petitioner has gone to the expense to reproduce, the panels should consider the relevant sections.

Grounds for reconsideration on party motion. Party sought reconsideration requires panel determination whether the decision exceeds Commission powers or was procured by fraud, material new evidence has been discovered, the evidence justifies the findings of fact or the findings of fact do not support the decision. ${ }^{110}$ How do the panels determine whether the evidence justifies the findings of fact?

By Commission rule the supporting evidence apparently must be "substantial."111 The substantiality standard suggests the test courts typically apply to administrative agency decisions. ${ }^{112}$ But the analogy's aptness is theoretically limited, for the panels, unlike the courts, may re-weigh the evidence. ${ }^{113}$ Actually the panels seldom re-weigh the evidence, and when

108 Pac. Empl. Ins. Co. v. IAC, 10 CaI. Conrp. Cases 150 (1945) Commission need not read cumulative or medically immaterial parts of record. See Jaffe, Judicial Review: Substantial Evidence on the Whole Record, 64 HARv. I. REv. 1233 (1951) for a discussion of a similar problem affecting the National Labor Relations Board.

109 Interview with members of San Francisco panel, April 23, 1952.

110 Rules, supra note $14, \S \S 10877,10878$. The major form of review is reconsideration. CAI. LAB. CoDE $\$ \$ 5900-5911$. Section 5903 provides the following exclusive grounds for reconsideration:

"(a) That ... the commission acted in excess of its powers.

(b) That the ... decision ... was procured by fraud.

(c) That the evidence does not justify the findings of fact.

(d) That the petitioner bas discovered new evidence...., which he could not, with reasonable diligence, have discovered and produced at the hearing.

(e) That the findings of fact do not support the order, decision or award."

Before the 1951 amendments, this proceeding was termed "Rehearing." In the past, the Commission bas considered itself the ultimate fact finder and has even been upheld in its reversals of referee credibility findings in demials of petitions for writs of review without opimion. See e.g. Barton v. IAC, 5 CAL. COMP. CASES 279 (1940). The courts have not closely interpreted the statutory language in relation to referee reversals. Query: Will they limit Commission reversal powers under the new referee system?

111 Rules, supra note $14, \$ 10870.5$ provides, "Where reconsideration is sought under the provisions of Labor Code Section 5903, upon the ground that findings are not supported by substantial evidence, such petition shall set out specifically and in detail wherein the evidence fails to support said findings." (Emphasis added.) Courts have similarly annended judicial review statutes by adding a substantiality requirement. Did the Commission intend to amend $\S 5903$ (c) by narrowing its scope or is the "substantial" test merely an additional ground of reconsideration? The former would seem indefensible.

112 See e.g. Car. Code CIv. Proc. § 1094.5(c).

113 CAL. LAB. CODE $\S 5903$. One of the grounds of reconsideration is "(c) That the evidence does not justify the findings of fact." Many court opinions assert the Commission's power to resolve the conflicts in the evidence. See e.g. Nat. Auto \& Cas. Co. v. IAC, supra note 104. This case really turns on hearing and deciding functions. Also see Idalıo Maryland Mimes Corp. v. IAC, 104 Cal. App. 2d 567, 232 P.2d 11 (1951); West v. IAC, supra note 51; Jenks v. Carey, 136 Cal. App. 80, 28 P.2d 91 (1933). See HaNNA, op. cit. supra note 8 , at 217.

But the allocation of deciding functions between the referees and the panels rarely is men- 
they do they accord great weight to referee findings. ${ }^{114}$ Referee credibility conclusions based on hearing room observations are given the greatest respect. ${ }^{115}$

But panel reversal of referees even as to credibility has been upheld. ${ }^{110}$ A fortiori, panel judgment may be substituted where the evidence weighing raises only materiality, relevancy, probity or reliability questions. ${ }^{117}$ Hence the panels are more disposed to find evidence insufficiency on these rather than credibility grounds. ${ }^{118}$

\section{Court Review}

Commission decisions are reviewable in California appellate courts by a statutory writ of review. ${ }^{110}$ Under the 1951 amendments to the review provisions, it must be determined upon the entire record whether the Commission acted without or in excess of its powers; the order, decision or award was procured by fraud, was unreasonable or was not supported by the findings of fact or by substantial evidence. There may be no trial de novo or independent judgment on the facts. ${ }^{120}$

Grounds for reversal. Referee deciding patterns are shaped by court reversals of decisions issued by the Commission but actually made by referees. Referees are aware that the courts ordinarily feel free to redecide questions of law and mixed questions. ${ }^{121}$ They are also aware that some courts feel remitted to the substantiality standard only when there is a "genuine conflict" in the evidence which presents a "pure" question of fact. ${ }^{122}$

tioned. See Bethlehem Steel Corp. v. IAC, 70 Cal. App. 2d 369, 381, 161 P.2d 18, 24 (1945). "... [I]t must be remembered that $m$ these cases it is the Commission and not the referee who makes the order." Also see Liberty Mut. Ins. Co. v. IAC, 73 Cal. App. 2d 555, 563, 166 P.2d 908, 913 (1946) wherem the court said the referee's iunction is to find facts, not declare the law.

114 Interview with panel members, supra note 109. See Manual, supra note 27, Art. $58(M)(2)$.

115 See e.g. House v. Foster \& Kleiser Co., 11 Car. Comp. Cases 216 (1946). Interview with panel members, supra note 109.

116 Barton v. IAC, supra note 108.

11 'See Jaffe, supra note 108, at 1258-1259, for view that relevancy is always a question for the courts.

118 Interview with panel members, supra note 109.

119 CAL. LAB. CODE $\$ 5900$. This is the exclusive method as to compensation awards. Loustalot v. Superior Court of Kern County, 30 Cal. 2d 905, 186 P.2d 673 (1947). For a good discussion of this writ see McGovney, supra note 53, at 115. Only the appellate courts have jurisdiction over Commission awards. CAI. LAB. CODE $\$ \S 5950,5955$.

${ }_{120}$ CAL. LAB. CODE $\$ 5952$. See recent discussion of this amendment in 40 CALIF. L. REv. 119 (1952).

121 But it is difficnlt to determine when a question of law is presented. Since the leading case of Ethel D. Co. v. IAC, 219 Cal. 699, 28 P.2d 919 (1934) court review seems to have been extremely narrow. For criticism of this review see Report on Administrative Agencies and Tribunals, supra note 19, at 318. Compare 40 CALIF. L. REv. 119 (1952). Whether an injury results from an employer's serious and wilful misconduct is a question of fact. Chick v. IAC, $107 \mathrm{Cal}$. App. 2d 292, 237 P.2d 8 (1951); Kaiser v. TAC, 81 Cal. App. 2d 818, 185 P.2d 353 (1947); Dawson v. IAC, 54 Cal. App. 2d 594, 129 P.2d 479 (1942). Whether a person is an einployee or an independent contractor is also a fact question. Calif. Coinp. Ins. Co. v. IAC, 86 Cal. App. $2 \mathrm{~d}$ 861,195 P.2d 880 (1948). If a material finding is not made on conflicting evidence a question of law is presented. Martin v. IAC, 82 Cal. App. 2d 737, 187 P.2d 101 (1947).

${ }^{122} \mathrm{~A}$ Commission finding opposed to the uncontradicted evidence will not be upheld. Firestone Tire Co. v. IAC, 93 Cal. App. 2d 23, 208 P.2d 44 (1949). And if "only a simgle inference and one conelusion may be drawn, whether one be an employee or an independent con- 
But few decisions are reversed because the evidence is not substantial. ${ }^{123}$ Most reversals seem to involve due process violations.

Due process reversals. Accordingly, the practitioner who has not waived his due process objection through failure of timely assertion, ${ }^{124}$ who can overcome the presumption of Commission procedure regularity, ${ }^{125}$ and who can demonstrate prejudicial error, not merely procedural irregularity, ${ }^{126}$ may accomplish annulment of unfavorable referee decisions.

Due process requires that the parties be properly served ${ }^{127}$ and receive adequate notice. ${ }^{123}$ Relevant and material cross examination of Commission, mdependent and opposition witnesses must be allowed. ${ }^{129}$ Opportunity to meet and explain secret or ex parte evidence must be afforded. ${ }^{130}$ There must be no proven referee bias. ${ }^{131}$

tractor is a question of law." Walder v. IAC, 85 Cal. App. 2d 473, 475, 193 P.2d 60, 61 (1948). Accord, Nat'l Auto \& Cas. Ins. Co. v. IAC, 80 Cal. App. 2d 769, 182 P.2d 634 (1947).

123 For an example of an award reversed as "unreasonable" see Campbell v. IAC, $95 \mathrm{Cal}$. App. 2d 570, 213 P.2d 395 (1950).

${ }_{124}$ The error must be asserted in the petition for reconsideration. Bethlehem Steel Corp. v. IAC, 106 Cal. App. 2d 373, 235 P.2d 125 (1951) ; Peak v. IAC, 82 Cal. App. 2d 926, 187 P.2d 905 (1947). See Stoll v. IAC, 20 Cal. 2d 440, 126 P.2d 865 (1942).

${ }_{125}$ See e.g. Lumbermen's Mut. Cas. Co. v. IAC, 29 Cal. 2d 492, 175 P.2d 823 (1946); Pac. Indem. Co. v. IAC, 28 Cal. 2d 329, 170 P.2d 18 (1946); Peak v. IAC, supra note 124; O'Hare v. IAC, 44 Cal. App. 2d 629, 112 P.2d 915 (1941). The Commission has successfully argued the burden of proving irregularities rests upon the petitioner. Pac. Emp. Ins. Co. v. IAC, 7 CAL. COAIP. CASES 91 (1942) (writ denied without opinion).

${ }^{126}$ See e.g. Colonial Ins. Co. v. IAC, 47 Cal. App. 2d 487, 118 P.2d 361 (1941). Writs denied without opinion: Waldon v. IAC, 10 CAL. CoMrr. CASES 148 (1945); Higgins Estate v. IAC, 9 CaL. Compr. Cases 124 (1944); Haines v. IAC, 6 Cad. Comp. Cases 181 (1941). Some writ denials without opinion in this area seem particularly inexplicable. See e.g. Pac. Indent. Co. v. IAC, I1 CaL. CoMpr. CaSES 221 (1946); London Guar. \& Acc. Co. Itd. v. IAC, 6 Cat. Comp. CASES 98 (1941).

127 Service by mail is adequate. Estremed v. IAC, 1 CAL. CoMrp. CASES 34 (1936) (writ denied without opinion). But service by mail is not effected where mail is returned unclaimed. Moore v. Floden, 14 Cad. Cossp. CASes 247 (1949) (Commission decision). Service must be made in comphance with CAL. CTv. CODE $\$ 406(a)$. Searles v. Southwestern Engineerimg Co., 5 Cat. Compr. Cases 219 (1940) (Conmission decision).

${ }^{128}$ Although notice is required, a later opportumity for full hearing will cure a failure to notify. Wilson v. IAC, 16 CAL. COMPP. CASES 204 (1951) (writ denied without opinion).

120 Langendorf United Bakeries Inc. v. IAC, 87 Cal. App. 2d 103, 195 P.2d 887 (1948); Mass. Bond. \& Ins. Co. v. IAC, supra note 51; Pac. Emp. Ins. Co. v. IAC, 47 Cal. App. 2d 713, I18 P.2d 848 (1941). A failure to subpoena a witness may be fatal. Bethlehem Steel Corp. v. IAC, supra note 124 .

The Commission nray limit the scope of the cross examination. Pabco Products Inc. v. IAC, 16 CAL. COMPP. CASES 60 (1951) (writ demed without opinion). A referee may cross examime one who can only nrake signs, and opponent who fails to try the sanie technique has not been denied an opportunity to cross examine. Bethlehem Steel Co. v. IAC, 8 CAL. CosIP. CASES 124 (1943) (writ denied without opinion). The Commission has confessed error for preventing cross-examination. Colonial Ins. Co. v. IAC, 7 CAL. Consp. Cases 127 (1942) (annulled and remanded with brief statement from court); General Assur. Corp. v. IAC, 6 CAL. Costr. Cases 165 (1941).

130 Mass. Bond. \& Ins. Co. v. IAC, supra note 51; Holmes Eureka Lumber Co. v. IAC, 41 Cal. App. 2d 150, 106 P.2d 23 (1940); Peters Metal Products Co. v. IAC, 10 CaL. Comrp. CASES 44 (1945) (award annulled without opinion). Cf. (all writs denied without opinion) Hardware Indem. Ins. Co. v. IAC, 13 CAI. Comp. CASES 18 (1948); Palmer v. IAC, 11 CAL. Compr. Cases 85 (1946); California Ala. Gold Mmes v. IAC, 5 CaL. Consp. Cases 161 (1940); The Borden Co. v. IAC, 3 Cat. Comp. Cases 70 (1938).

131 J. G. Boswell Co. v. IAC, 67 Cal. App. 2d 347, 154 P.2d 13 (1944); cf. Bethlehen Steel Corp. v. IAC, supra note 113; Gen. Motors Corp. v. IAC, 12 CAL. CoMrp. Cases 209 (1947) 
Referee decisions and the Morgan Case. Compensation due process litigation has frequently involved the force of the Morgan case doctrine that "the one who decides inust hear." "132 It assumes importance in two inajor situations: (1) where the deciding referee hears none or less than all the evidence and (2) where the reviewing panel hears none of the evidence.

To a lesser extent now than formerly, exigencies necessitate that hearings in the same case be conducted before different referees. ${ }^{133}$ This in itself need involve no due process denial. ${ }^{134}$ But unless the parties stipulate that the referee who heard part of the evidence may decide the case on the record and the other referee's report, ${ }^{135}$ or unless the unheard evidence is deemed unnecessary, ${ }^{136}$ it seems that the deciding referee must review both the record and the transcript of the hearing in which he did not participate. ${ }^{18 \pi}$ Actually the stipulation technique has proven very successful.

It may be argued that in the absence of a stipulation the referee who decided, after hearing part of the testinony, should be required to study the transcript only when there appear to be inconsistencies between the evidence adduced in the hearing before the deciding referee and the record of the earlier proceeding, including the referee's report. This would not only save time and the expense of reproducing the testimony, but also would afford substantial due process. ${ }^{138}$

\section{ROLE OF LAWYERS}

Compensation contestants are increasingly represented by lawyers, ${ }^{130}$

(writ denied without opinion); Colonial Ins. Co. v. IAC, 12 CAI. Comp. CASES 52 (1947) (writ denied without opinion).

132 Morgan v. United States, 298 U.S. 468, 481 (1936). An excellent discussion of the modem significance of the doctrine of this case is found in Davis, AdMINISTRatrve LAw c. 8 (1951).

${ }^{133}$ Referees hold hearings regularly in various communities in the state. For several years, however, the Commission has made every effort to so adjust calendars that continued hearings are held before the same referee unless it is unavoidable. See HANNA, op. cit. supra note 8 , at 206-207, 222. There is a dire need for branch offices. See 1951 Partial Report, supra note 4, at 201-6. Recently one was established in Sacramento.

134 CAL. LAB. CoDE $\$ 5310$ specifically grants the Commission power to transfer proceedings to another referee. See Assoc. Indem. Corp. v. IAC, 10 CAI. CostP. CASES 127 (1945) (writ denied without opinion).

135 See HANNA, op. cit. supra note 8, at 222.

${ }^{136}$ See e.g. Colonial Ins. Co. v. IAC, 47 Cal. App. 2d 487, 118 P.2d 361 (1941). The deciding referee didn't read the transcript, but all the evidence relevant to the disputed issue was received before the second referee. In Santa Maria Gas Co. v. IAC, 46 Cal. App. 2d 775, 117 P.2d 951 (1941) the court held evidence introduced before deciding referee sufficient as a matter of law and termed evidence before first referee unnecessary.

137 Helmick v. IAC, supra note 103; Deter v. IAC, 45 Cal. App. 2d 664, 116 P.2d 112 (1941); Bethlehem Steel Co. v. IAC, 42 Cal. App. 2d 192, 108 P.2d 698 (1940); Taylor v. IAC, supra note 104; Pac. Emp. Ins. Co. v. IAC, supra note 125; Hicks v. IAC, 6 CAL. CoMp. CASES 217 (1941) (annulled and remanded by stipulation). But see Elliott v. IAC, 12 CAx. CoMp. CASES 38 (1947) (writ demied without opinion) in which it does not appear whether the transcript was read by the second referee'although the record was read.

138 On reconsideration the burden could be placed on the petitioner to point to the testimony which, if read, might have produced a different result.

${ }_{139}$ In 1951 injured employees were represented in 67.1 per cent of all original decisions and 78.4 per cent of all supplemental decisions. 1951 StaTISTICAL Sumarary, stipra note 3.75.8 per cent of the successful employee applicants in original decisions and 89.1 per cent in supplemental decisions were represented. Ibid. These figures include both lawyer and laymen representatives.

Comparable statistics as to employers and insurers were not published in 1951. However, they are virtually always represented. 
despite permissive layman representation, ${ }^{140}$ the small sums individual claims usually involve ${ }^{141}$ and the controlled fee system. ${ }^{142}$ Attorneys do not confine themselves to hearing room appearances. A greater portion of their efforts are devoted to claim investigations, settlement efforts, hearing preparation and post-hearing activities.

Adequate representation of injured workmen is a difficult problem in view of the competing policies of keeping the award largely intact for the claimant, and of properly rewarding the representative for his services. In adjusting these policies, the legislature has denied judicial enforcement or Commission imposition of liens for fees beyond an amount determined reasonable by the Commission. ${ }^{143}$ Unreasonable fee agreements apparently are merely voidable. ${ }^{144}$ The Commission's determination of reasonableness has been reviewed by the courts. ${ }^{145}$ In 1951 the average fee awarded by the Commission in original decisions was $\$ 100.10 .{ }^{146}$ There is little published

140 CAI. LAB. CODE $\$ 5700$. . . "Either party may be present at any hearing, in person, by attorney, or by any other agent, and may present testimony pertinent under the pleadings."

$1.4180 .1 \%$ of all 1951 original decisions, compromises and releases involved less than $\$ 2,000$. $\mathbf{5 1 . 7 \%}$ involved less than $\$ \mathbf{7 5 0}$. The average award figure is not calculated.

Those totally dependent upon deceased employees may not receive in excess of $\$ 400$ for burial expenses, plus $\$ 8,750$ as death benefits and plus indemnity benefits, if the injury causing death occurred after certain 1949 amendinents, CaI. LaB. Code \$§ 4701-08. See Hanna, TaE WORKaren's COMrpensation LAWs OF CaIIFORNIA 178 (1951) for a table of death benefits. No disability payment is recoverable for the first seven days after an employee leaves work, CAL. LAB. CoDE $\$ 4652$, unless the disability is temporary and exceeds 49 days, Car. LAB. CoDE $\$ 4650$. The usual temporary disability payment is $65 \%$ of the average weekly eamings, CAL. LAB. CODE $\$ \S 4653-4654$. Permanent disabilities are compensable at $65 \%$ of average weekly wages, modified by a schedule, in which account is taken of the nature of the employee's injury, his occupation, age and ability to compete in an open labor market, CAL. LAB. Code $\$ \S 4658-4663$. See HanNA, op. cit. supra at 174-177.

The employer who neglects or refuses to provide reasonably required medical, surgical and hospital treatment, imcluding artificial members is liable for such expenses as are reasonably incurred, CAL. LAB. CODE $\$ 4600$. The einployer must reinburse for expenses reasonably incurred for $\mathrm{x}$-rays, laboratory fees and medical reports required to successfully prove a contested claim, ibid. The charge for self-procured treatinent is presumed to be reasonable. See Rules, supra note 19, § 10803. X-rays and medical reports which assist the Commission to favorable employee awards are considered to have been required, id., \$10804. A schedule of minimum fees for medical service is provided. Although this schedule is filed as required by the California Administrative Code, it is separately published. See HANNA, op. cit. supra at 200-209.

142 See note 146 infra.

143 See Car. LaB. Code $\$ \S 4903$ (a), 4905-7.

144 Schilling v. IAC, 47 Cal. App. 190, 190 Pac. 373 (1920). Dehberate overcharging is discouraged by the Commission's control over its attorneys through its power to deny the privilege of practice before it and to invoke the State Bar's disciplinary functions. See HaNNA, op. cit. supra note 8, c. 15.

145 Bentley v. IAC, 75 Cal. App. 2d 547, 171 P.2d 532 (1946).

146 The average fee was $\$ 130.04$ in supplemental decisions. Fees were awarded in a little more than a third of the original decisions but in almost a half of the supplementals. STATrstrcat Sudarary, op. cit. supra note 3 . Fees are not awarded in all cases and in some cases fees are settled by voluntary agreement. During 1951 the four highest fee totals the Commission's northern panel awarded applicant representatives were $\$ 23,230 ; \$ 18,115 ; \$ 15,140$ and $\$ 11,892$. But only eleven out of 210 applicant representatives who appeared before the northern pancl in 1951 received fees in excess of $\$ 3,000$ during the year. Figures supplied by Mr. Nelson, Commission Chairman's Administrative Assistant. 
criticism of Commission practice under this system. ${ }^{147}$ As a result of the system, however, a small group of claimant specialists who can handle compenation cases in volume has arisen within the state bar. Consistently with Commission encouragement of party settlements, more liberal attorney fees are allowed under compromise and release agreements. It is doubtful whether this is a desirable practice despite a sincere motive to reduce litigation.

A case may be made that injured workers need not be represented by counsel at the hearing stage when the facts and issues are simple. ${ }^{148}$ But increasingly fewer simple cases are contested through the hearing stage. More often hearings in simple cases are avoided. And whether avoided or not, the typically legal tasks of investigation, preparation and negotiation must go on.

The widespread notion, rapidly losing prevalence, that lawyers are unnecessary in compensation practice is an oversimplified generalization based primarily on three factors. (1) Laymen may and do engage in compensation practice; ${ }^{149}$ (2) Referee participation in hearings sometimes seems to make representation unnecessary ${ }^{150}$ and (3) the Commission performs many functions lawyers are accustomed to performing in our judicial system..$^{151}$

Actually most parties to hearings are represented by skilled specialists. They are necessary when the facts or issue are complex, difficult legal or medical questions are involved, or testimonial evidence (especially from opposing witnesses) is to be elicited. ${ }^{\mathbf{1 5 2}}$

State, private and self insurers utilize the services of a small select bar and experienced compensation claim adjusters. ${ }^{153}$ Most employees are represented by a few law firms which specialize and by union officials experi-

147 Apparently the nature of the cases and the peculiarities of the practice have thus far softened complaints. See Allen, Fixing of Attorney's Fees by the Industrial Accident Commission, 7 CALIF. State B.J. 234 (1932). But see 8 NACCA L.J. 96 (1951) and comments there cited. See generally note 159 A.L.R. 912 (1945).

148 See testimony of Burke, 1951 Partial Report, supra note 4, at 285. But see testimony of Referees Batistich and Barry who see a need for attorneys in all cases, ibid. See also 9 CaIIr. State B.J. 72 (1934). But there are cases where, "with an experienced referee presiding, the claimant will prevail, though with an attorney of but indifferent capacity." See Allen, supra note 147 at 236 .

149 CAL. LAB. CoDE $\$ 5700$. Non-lawyers represent applicants, employers and insurers. See note 140 supra.

$150 \mathrm{CAL}$. LAB. CODE $\S 5708$. A referee "may make inquiry in the manner . . . which is best calculated to ascertain the substantial rights of the parties ...." Commission rules impose upon referees the duty to get the truth. See Manual, supra note 27, Art. 38, § 21(D) (c). See Allen, supra note 147 at $237-8$.

${ }^{151}$ See $i d$. at $237-9$ for list of services the Commission performs which, in a civil case, a lawyer would necessarily perform.

152 See $i d$. at 235-6 for an analysis, for fee determination purposes, of the need for representation based on whether (1) a representative nay change the benefits one way or another; (2) an award may be certain, but an additional amount is contested; (3) a claimant may win or lose in toto; (4) a claimant will win thougl indifferently represented. See HaNNA, op. cit. supra note 8 at 320 . "In a large number of cases legal representation is indispensable ....."

153 The State Compensation Fund uses specialists on its own legal staff. Many self and private insurers use specialists among their own attorneys and claims adjusters. Others retain firms which specialize in compensation practice. 
enced in compensation practice. General practitioners represent some employees, but often they refer their clients to specialists who can efficiently and profitably handle a large volume of cases with a minimum of wasted effort. ${ }^{154}$ The referees prefer that the parties be competently represented but insist that specializing laymen are often more effective than attorneys engaged in general practice.

The expertness an able compensation practitioner must possess compares favorably with that required in many other specialized fields of the law. He must not only be thoroughly acquainted with the state compensation laws but also with related state and federal laws which pose difficult jurisdictional problems. ${ }^{155}$ Even within the state compensation laws myriad questions of substantive and procedural law, tactics and timing arise. ${ }^{156}$

Investigating compensation case facts is neither more nor less important than is the investigative phase in any other judicial or administrative fact finding proceeding. ${ }^{157}$ An investigation's scope will be determined by the sums and the number, importance and kinds of issues involved. Usually the establishment of a claimant's prima facie case showing injury arising out of and in the course of employment requires little investigating. ${ }^{158} \mathrm{But} \mathrm{em}$ ployer burdens of rebutting or asserting affirmative defenses to this prima facie case frequently require intensive investigation. ${ }^{159}$ However, in certain instances applicant investigative activity is essential. ${ }^{160}$

1041951 Partial Report, supra note 4, at 284-5. See testimony of Silverberg, Bachelis and Ratner.

155 Among the laws with which a California compensation practitioner must be familiar are the Longshoremien's and HARBor Workers Comirensation ACT, 44 Stat. 1424 (1927), 33 U.S.C. 902 (1951 Supp.) ; FederaI EMIPLOYERS' LiabIITTY ACT, 35 STAT. 65 (1908), 45 U.S.C. 51 (1951 Supp.); Federal Safety Appltance ACT, 27 Stat. 531 (1893), 45 U.S.C. 24 (1951 Supp.); Jones ACT, 38 Stat. 1185 (1915), 46 U.S.C. 688 (1948 Supp.); Higri Seas DeatH ACr, 41 Stat. 537 (1920), 46 U.S.C. 761 (1948 Supp.); and DefEnse BASE Act, 55 StaT. 622 (1941), 42 U.S.C. 1651 (1951 Supp.).

There are also California statutes to be dealt with. For example, the UNEMrPLOYMENT INSURANCE ACT, Cal. Stats. c. 274 Calif. Legislature, 1st Extra Session 1946. See HANNA, op. cit. supra note 8, c. 5-7, and Edises, Multiplicity of Remedies in the Field of Industrial Accident Lare, 21 CAITF. L. Rev. 430 (1933).

156 For example, should the remedy be sought under the California Act or under the act of another state. If the Cahifornia Act is chosen should a claim be filed? When? Should a negligence suit also be filed? Against an employer? Against a third party? Who sloould examine the applicant? When? Is the Subsequent Injury Fund imvolved? Should a compromise be negotiated? When? Usually these questions arise before learing. Many more may arise during and after a hearing.

See Campbell, Where and How of Administrative Law Practice in California: Industrial Accident Commission, 18 CALIF. STATE B.J. 177 (1943). In presenting a minimal California bibliography lie wrote, "A great mass of material which a practitioner needs about "how to get in' and 'how to stay in' and 'what to do then' is not ordinarily available." Id. at 191.

$157 \mathrm{It}$ is the nature of the claim and its surrounding circumstances which create the need for investigation. See thorough chapter on "The Investigation of Compensation Claims" in HanNa, op. cit. supra note 8 at 356. "Claims investigation by insurance carriers has become a well organized and highly specialized procedure." Id. at 358.

$105 \mathrm{Few}$ applicants experience difficulty in showing a prima facie case. Usually the referee quicky establishes whether it exists by his preliminary questioning. See text at note 68 supra.

169 The defendant bears the burden of proving the applicant was an independent contractor; not covered by the law; intoxicated; or engaging in wilful misconduct. He also bears the burden of showing that the applicant aggravated his disability; prejudiced the employer 
Effective pre-hearing and hearing preparation requires the same consideration of a mass of litigative details that confronts the lawyer preparing a trial before a judge without a jury. In addition to the facts and the applicable substantive law, the effect of the statute, decisions and rules upon well known court room procedures must be studied. Special Commission practice requisites must be grasped as to such matters as the statutes of limitations; ${ }^{161}$ venue; ${ }^{162}$ concurrent, continuing, divided, exclusive and extra-territorial jurisdiction;103 "simplified" pleadings and the Commission's many suggested forms; ${ }^{164}$ depositions and interrogatories; ${ }^{105}$ stipulations $;{ }^{166}$ party joinder $;{ }^{169}$ order and manner of proof $;^{168}$ burden of proof $;^{100}$ presumptions; ${ }^{170}$ and objections. ${ }^{171}$

through lack of proper notice, CAC. LAB. CODE $\$ 5705$; or failed to file within the applicable statutory period. Id. $\$ 5409$. There are other affirmative defenses. See HaNNA, op. cit. sitpra note 8 , at 216-17. There are also conclusive and disputable presumptions to be dealt with. $I d$. at 214-16.

160 For example, to determine whether the employer was guilty of serious and wilful misconduct, to provide a medical history, to question witnesses, to rebut an independent contractor defense, etc.

101 CAL. LAB. CODE $\$ \$ 5400-5412$.

162 There are no statutory provisions. The Commission fixes venue usually for the applicant's convenience. See Manual, stlpra note 27, Art. 38, §1. Also see HaNva, op. cit. silpra note 8, at 206.

163 Id. c. 4.

164 Only an application is required before an original hearing. CAL. LAB. CODE $\$ \$ 5500-5501$.

By Commission rule an answer is not required though recommended and urged, Rulles, supra note 18, $\$ \$ 10730-10734$. One is not ordinarily filed except to set up an affirmative defense, HANNA, op. cit. supra note 8, at 307. A failure to file an answer does not constitute an admission, O'Hare v. IAC, 44 Cal. App. 2d 629, 112 P.2d 915 (1941). There are no defaults, Rules, supra note $18, \S 10734$.

"... [T] amendinent at the hearing and proceeds to hear the matter upon all issues there with due regard to the rights of the parties prejudicially surprised thereby." Mantal, supra note 27 , Art. $60, \$ 3$.

For administrative control, convenience and simplicity the Commission provides more than a score of forms to be filed at various stages of a claim. See Mansal, suspra note 27, Art. 35 for complete list. Also see HANNA, op. cit. supra note 8, at 194.

165 CAL. LAB. CODE § 5710. "Depositions" is a statutory term. "Interrogatories" is added by Commission rule. See Mamual, supra note 27, Art. 44.

166 The Commission may take further evidence despite stipulations, CAL. LAB. CODE $\$ 5702$. They bimd the parties but not the Commission, Rules, supra note 14, § 10744. See Mantal, stipra note 27, Art. 38, $\$ 9$ and Art. 70. Jurisdiction of the subject matter may not be conferred on the Commission by party consent. Zurich Co. Ltd. v. IAC, 191 Cal. 770, 218 Pac. 563, cert. denied 263 U.S. 722 (1923). Compare Employers' L.A. Corp. v. IAC, 177 Cal. 771, 171 Pac. 935 (1918) which holds that the parties may stipulate to the existence of facts which bring a case within the jurisdiction of the Commission.

167 CAL. LAB. CODE $\$ 5303$. "There is but one cause of action for each injury. . . . All claims ... or any other matter arising out of such injury may ... be joined ...." Also see occupational disease party jomder provision added in 1951, CAx. LAB. CoDE $\$ 5500.5$. See Rulles, supra note 18, \$9760-9764 and Manual, supra note 27, Art. 45.

168 CAL. LAB. CODE $\$ \$ 5708-5709$. See Manual, supra note 27, Art. 38 for detailed instructions regarding referee hearing room conduct.

169 CAL. LAB. CODE $\$ 5705$. See note 159 , supra.

170 See HaNNA, op. cil. supra note 8, at 214-216.

171 "Technical objections to the admission of evidence are not favored. However, the California Supreme Court has held that incompetent evidence admitted without objection can become the basis of an award. It is the right of adverse counsel to make reasonable objections to save his record." Mantal, supra note 27, Art. 38, §21(D)(d). 
The role the medical and permanent disability rating bureaus perform in giving formal and informal opinions, frequently decisive of claims, must be understood. ${ }^{172}$ Complicated disability rating schedules must be dealt with. ${ }^{173}$ Lien and subrogation problems arise. A working knowledge of industrial medicine should be acquired.

In view of these requisites, it should occasion no surprise that some of the most successful compensation attorneys are former referees. An inexperienced employee representative may achieve limited success from a single referee hearing but he may fail to realize for his client the full benefits of the law. Even his limited success may be due as much to referee efforts as to his own.

\section{IACK OF INFORMATION}

Unfortunately, both for lawyers and for students of public administration, little has been published concerning the procedural aspects of workmen's compensation. ${ }^{174}$

California's compensation procedures developed almost unnoticed by the legislature. Thirty years elapsed between the legislature's enactment of California's first compulsory compensation law ${ }^{175}$ and the first legislative investigation of Commission procedures. ${ }^{176}$ However, an awakening legislative interest is evidenced in the activities of a Senate Interim Committee which has already issued several instructive reports and is continuing its studies into the 1953 legislative session. ${ }^{17 \tau}$ Thus careful legislative planning and draftsmanship may not be too much to hope for.

With notable exceptions, legal journal treatment has been sparse. ${ }^{178}$ But

${ }_{172}$ See HanNa, op. cit. supra note 8, at 82-86.

173 See 1951 Partial Report, supra note 4, at 55-68, 101-147 for analysis of permanent disability rating plans of California and other jurisdictions. The committee reported that very few people in California are sufficiently expert to arrive at the same rating as does the rating bureau in any but the simplest cases. Id. at 15 . A new schedule was adopted by the Commission and went into effect July 1,1950 . See portion of schedule, not modified for age or occupation, HANNA, op. cit. supra note 141 at 174-177.

${ }^{174}$ See note 7 supra. See Bear, Survey of the Legal Profession-Workmen's Compensation and the Lawyer, 51 Cor. L. Rev. 965 (1951) for a criticism of increasing complexities which have crept almost unnoticed into American compensation systems.

175 TrE Boynton Acr, Cal. Stats., c. 176 (1913), effective January 1, 1914.

${ }_{176}$ The results of this investigation were reported to the legislature in the 1945 regular session. See 1945 Partial and Final Reports, supra note 8.

177 See 1951 Final Report, supra note 4; 1951 Partial Report (Filed May 11, 1951), supra note 43; an earher 1951 Partial Report (Filed April 13, 1951), supra note 4; 1949 Report, supra note 50;1947 Report, supra note 50. These have been described as the most comprehensive recent reports by legislative committees. See Riesenfeld, Basic Problems in the Administration of Workmen's Compensation, 36 MINN. L. REv. 119, 120 n. 6 (1952).

Also see the Preliminary and Final Reports of the Assembly Interim Committee on Finance and Insurance. Calif. Legislature, 1950 Reg. Sess., for the results of a study of the State Compensation Insurance Fund.

178 The most noteworthy exception has been the State Bar Journal. See e.g. Report on Administrative Agencies and Tribunals, supra note 15; Campbell, Where and How of Administrative Law Practice in California: Industrial Accident Commission, 18 CAITF. STATE B.J. 177 (1943); Trowbridge, note 20 supra; Report of Committee on Practice and Procedure Before the Industrial Accident Commission, 9 CALrF. STATE B.J. 72 (1934) and Allen, supra note 147. Also see Gallagher, supra note 23; McGovney, supra note 23; Pillsbury, Applicability of 
for the treatises published by Douglas Campbell and Warren Hanna, California compensation practitioners would be greatly disadvantaged. ${ }^{170}$ Even so, both authors have found difficulty in keeping their works abreast of rapid changes in the law, and have been forced into efforts to provide current inaterials. ${ }^{180}$

A voluminous set of mimeographed procedural rules the Commission furnishes to its referees may be examined at the Commission's office, but it is not otherwise published. A State Bar Committee considers these unpublished rules more important than the Commission's published procedural rules, and recommends that they be made more freely available to practitioners. ${ }^{181}$

Since the Commission's early days, formal opinions disclosing the reasons for claim dispositions have been dispensed with. ${ }^{182}$ Court opinions rarely differentiate referee from Commission conclusions. ${ }^{183}$

The Commission does not publish a periodic report, and only an inadequate substitute is found in the few pages the Director of the Department of Industrial Relations devotes to the Commission in its reports to the Governor's Councils. ${ }^{184}$ Only within the last few years have statistical analyses become available. Although they promise well for the future their present usefulness for research is limited. ${ }^{185}$ A splendid opportunity for Commis-

Methods to Civil Actions, 18 CAIIF. L. REv. 223 (1930); Pillsbury, An Experiment in Simplified Procedure, 3 CALIF. L. REv. 181 (1915).

Brief summaries of compensation matters have appeared in the three volumes of the Anmal Survey of Califormia Lav which have been issued since 1949. These may stimulate more detailed treatment of procedural problems.

${ }^{179}$ See 1 and 2 Campbelx, Workaren's Compensation Insurance, Princtpies and PracTICE (1935). Douglas Campbell is still an active referee serving in the Los Angeles office of the Commission. See Hanna, Industrial Accident Comomission Practice and Procedure (1943). Warren Hanna is a former referee.

180 Campbell has recently published a looseleaf supplement to his volumes, Carapdert, CAIIFORNIA WORKMEN's COMIPENSATION OUTLINE (1952) which treats current statutory and decisional materials. Hanna edits and publishes The Workmen's Compensation Laws in which are reproduced all relevant statutory provisions, the Commission's rules, and a topical case index. The latest edition is for use during 1951-53.

181 See Report on Administrative Agencies and Tribunals, supra note 15 at 316-317.

182 See McGovney, supra note 23 at $268-9$. The reason usually assigned is the steadily increasing volume of claims the Commission handles. However, the need for written opinions, in view of the new power of referees to inake original decisions, commands that this reason be examined in the hight of all present possibilities.

183 Inasmuch as formerly all decisions technically were "Commission" decisions, see note 15 supro, courts have seldom examined referee conclusions on their merits as opposed to "Commission" conclusions. Moreover, usually the testimony is not transcribed unless the court grants a petition for review. For an expression of judicial dissatisfaction with this practice see Satchell v. IAC, 94 Cal. App. 2d 473, 474, 210 P.2d 867 (1949). Most court decisions involving referee reversals go off on due process grounds. See e.g. Helmick v. IAC, supra note 137; Taylor v. IAC, supra note 137; Deter v. IAC, supra note 137. See Darling v. IAC, 67 Cal. App. 2d 300, 154 P.2d 421 (1944) for illustration of Commission refusal to accept referee report followed by the referee's issuance of a supplemental memorandum in accordance with the Commission's views.

184 These reports are issued monthly and biennially. Usually they contain only a digest of a few important court opinions and a summary of filing and decision statistics. See Carm. DEP'T. OF IND. REL., REPORTS TO GOVERNOR'S COUNCIr.

185 For 1950 and 1951 the Labor Statistics and Research Division of the Department of Industrial Relations has prepared annual statistical summaries of Commission decisions which are fairly comparable to each other. These summaries primarily stress factors affecting the speed 
sion procedure analysis was lost when the State Administrative Procedure Act framers excluded the Commission from its administrative agency study. ${ }^{186}$

In view of the general lack of published evaluations of compensation procedures, observation and interview techniques must bridge the gap between the law on the books and the actual practice. However, the writer hopes that in the next few years these techniques will have decreased in importance as a result of further Commission, legislative and law journal analyses.

\section{CONCLUSION}

Workmen's compensation procedures increasingly must be subjected to the critical scrutiny of an informed bar and public. Neither personnel, budget nor other considerations should prevent the Commission from publishing and making easily available detailed periodic reports, reasoned opinions, all rules and regulations and adequate statistical information essential to this scrutiny.

The ultimate goal should be to suggest procedures which will most efficiently inplenient the expanding substantive law. Procedural reforms cannot be left to fortuitous and temporary compromises between the expedience-dictated tugs and pulls of labor and employer groups. They must result from deliberate long range planning directed toward maximum realization of the state's policy to shift to the public, through employers and their insurers, the burden of work induced injuries from the workman and public and private welfare agencies by inexpensive, speedy and non-technical procedures.

The referee system deserves special consideration from lawyers. This is especially true in view of the newly won referee authority. Lawyers engaged in compensation practice should help provide the responsibility which accompanies this authority by insisting upon adherence to the applicable statutes, the published Rules of Practice and the general principles of Commission policy embodied in the unpublished Manual of Procedure.

Every aspect of compensation procedure is fair game for commentators. Critical analyses should be published in law reviews and other periodicals for the benefit of the legislature, the Commission, the bar and the public. The risls of disinterest are to ignore the potential of this state's growing hundred million dollar business and to sanction increasing complexities and perplexities.

with which claim dispositions are achieved. But they also seek to show types of injuries, employee age and sex, types of disabilities, compensation rates, employee representation, number and kinds of issues and amount of compromise and release dispositions. Despite recent improvements, however, a major portion of the job of providing statistics which will accurately, intelligibly and fairly completely describe Commission operations remains to be done.

186 The survey of administrative procedure which preceded the enactment of the California Administrative Procedure Act was limited to the adjudicative aspects of "agencies engaged in licensing and disciplining the members of the various professions and occupations." Calif. Judicial Councr Tente BIEnniat Report 10 (1944). The only provisions of the A.P.A. made apphicable to the Industrial Accident Commission are Articles 2 and 3, under which Commission procedural rules must be filed with the Secretary of State and published in the California Administrative Register and Administrative Code. See CAL. Govr. Code § 11445. 